\title{
Mathematical Astronomy and the Production of Multiple-Texts Manuscripts in Late Medieval Europe: A Comparison of BnF lat. 7197 and BnF lat. 7432
}

\begin{abstract}
This article takes on the idea that, at least in some contexts, when producing manuscripts certain protagonists were learning, fostering and promoting mathematical astronomy. It also seeks to improve our understanding of the articulations between producing astronomical manuscripts and other astronomical practices in the specific context of late medieval Europe. In tackling this issue one is compelled to rely on approaches used within the history of mathematical astronomy and those of manuscript cultures. In so doing, I focus on two manuscripts both relating to the same protagonist: Conrad Heingarter, a fifteenth-century astrologer cum physician in France. By analysing the material, decorative and intellectual aspects of BnF lat. 7197 and BnF lat. 7432 I will reveal how the first is a student manuscript produced during Heingarter's university years, whereas the second is a presentation manuscript intended to showcase Heingarter's competence in a specific courtly context.
\end{abstract}

\section{Introduction}

In a given historical context, what we currently describe as mathematical astronomy is a set of practices unified by the broad aim of proposing a mathematical account of celestial phenomena. Among these practices one finds computation practices, observational practices, various kinds of reasoning and argumentation practices, the design and use of instruments and numerical tables, etc. However, this article aims at a more fundamental practice often related to

The research presented in this article began in November 2016 on the occasion of the international conference 'The emergence of Multiple-Text Manuscripts' in CSMC Hamburg. A preliminary version of this research was also presented in 2017 in the "History of Sciences / History of Texts' seminar of the Sphere Laboratory in Paris. I am thankful to the organisers and participants of these events for their inspiration, insight, patience and encouragement. This research also benefits from the support of the ERC project ALFA, 'Shaping a European scientific scene: Alfonsine astronomy’ (CoG 2016 agreement no. 723085). 
mathematical astronomy in interesting and mostly unknown ways. This article explores the view that, at least in some contexts, actors were learning, fostering and promoting mathematical astronomy by producing manuscripts. It also seeks to improve our understanding of the articulations between producing astronomical manuscripts and other astronomical practices in the specific context of late medieval Europe.

At the end of the European Middle Ages, the geometrical diagrams, numerical tables and various kinds of texts used in the study of celestial phenomena were commonly collected in multiple-text manuscripts (MTMs). Many manuscripts of the astral sciences from fourteenth- and fifteenth-century Europe were produced in medieval universities. The main way to produce these manuscripts is through the well-documented pecia system. ${ }^{1}$ However, this kind of manuscript, with its possible marginalia indicating uses by students or other kinds of actors, does not exhaust the production of scientific manuscripts. ${ }^{2}$ First, medieval universities induced other kinds of manuscript production mainly around the master-student relationships. 'Students' manuscripts' were produced in the context of these relationships. In these manuscripts a given student copied and collected a set of texts of interest to him, which are generally more advanced than the basic-curriculum texts usually included in pecia manuscripts. On the other pole of the relationship we find 'masters' manuscripts' where the teachings of a given master are gathered. ${ }^{3}$ Of course, all kinds of intermediary and hybrids exist between these poles. This diversity is especially important for astral sciences, which was taught only at an elementary level in the official curriculum of most art faculties, but in some cases was practised at a much higher level and well beyond universities. For instance, the production of almanacs and ephemerides attest that an interest in astronomical topics was alive in various contexts of practice, and was often related to astrology and medicine, especially in urban milieus. Monasteries were another context where a minimal practice of astronomy was required at least for questions of time reckoning and coordination of the collective life. Ruling elites also manifested an interest in astronomy as the figure of the court astrologer cum physician attests in many

1 Brizzi / Tavoni 2009 and Bataillon / Guyot / Rouse 1988.

2 See for instance MS Escorial O II 10 and on this particular manuscript: Beaujouan 1965, Beaujouan 1974, Gushee 1970, Husson 2016.

3 It seems to be more the case in natural philosophy or theology than in the mathematical sciences, maybe reflecting different teaching practices. 
historical instances. ${ }^{4}$ Finally, even the highest church circles recurrently concerned themselves with astral sciences in the context of calendar reform. ${ }^{5}$

In principle, each of these practice contexts may induce specific types of manuscripts. In turn, each manuscript offers a unique lesson about the various ways historical actors incorporated the production and uses of codices in their astronomical practices. Our hypothesis is that manuscripts showing a different balance in the way the actual manuscript production is articulated to astronomical practices are the result of different kinds of production acts and undergo different kind of circulations. These would leave clues in the current circulation state of the manuscripts that can be analysed. Building awareness on how different types of astronomical manuscripts point to their production and circulation contexts is also fundamental for the history of astral science. Tackling these issues implies to rely on approaches from the history of mathematical astronomy and that of manuscript cultures. ${ }^{6}$ On the long term a possible outcome of such a research could be a typology of mathematical astronomy manuscripts organised around the dialectic relation between manuscript production and astronomical practices.

I intend to approach this issue by focusing on two manuscripts which are both related to the same actor: Conrad Heingarter, a fifteenth-century astrologer/physician in France. ${ }^{7}$ The BnF collection now holds eight manuscripts related to Conrad Heingarter (lat. 7197, lat. 7273 (?), lat. 7295A (?), lat. 7314 (?), lat. 7432, lat. 7446, lat. 7447, lat. 7450) ${ }^{8}$, from which I selected two that contain a version of the Alfonsine tables and their canons by John of Saxony. ${ }^{9}$ This set of texts and tables is a marker of Alfonsine mathematical astronomy, which was mainstream during this period in Latin European contexts. However, the analysis will show that the manuscripts were produced at different moments of Conrad Heingarter's career, and for different purposes. The first, BnF lat. 7197, was produced while Conrad Heingarter was learning mathematical astronomy. The second, BnF lat. 7432, was produced later in Conrad Heingarter's career in order to demonstrate and promote his competences to a patron.

I will describe and compare both manuscripts with respect to three dimensions: first, the material and codicological features; second, the aspects of writ-

4 Boudet 1994.

5 Nothaft 2018.

6 Andrist / Canart / Maniaci 2013.

7 Born in Horgen Switzerland near Zurich, Conrad Heingarter is a Parisian master of arts in 1455. In 1466 he became master in Medicine. See Wickersheimer / Beaujouan 1979, (I) 107.

8 Juste 2015.

9 Poulle 1984, Chabás / Goldstein 2003. 
ing, decoration and marks; third, the contents. ${ }^{10}$ Each of the elements described could require a full-length paper for its analysis. Thus, some aspects of the manuscripts might be overlooked. The descriptions are only meant to collect specific features that allow us to tackle the general issues presented above. From these descriptions, and following a method mainly inspired by La syntaxe $d u$ codex, ${ }^{11}$ I will try to reconstruct the part of the history of these two codices which is in my analytical reach. I will then build from these results and propose hypotheses: first with respect to the way the production of these types of manuscripts is a part of, and an interaction with, astronomical practices; and second, with respect to the way these manuscripts document the various milieus to which they are related in one way or another.

\section{Material features of the manuscripts}

\section{BnF lat. 7197}

BnF lat. 7197 is a 130-folios manuscript of approximate dimension $295 \times 210$ mm. ${ }^{12}$ The binding is restored from a fifteenth-century one. Much of the fifteenth-century binding is still extant. We can find wood boards covered with brown calf leather. Small blind-stamp decorations (lilies, finial, and quatrefoil) decorate the front, side and back cover. They probably can also be dated to the fifteenth century. Traces of iron clasps from the original binding are clearly visible. Remains of nails in the front and back cover are found. The leather is damaged because of frictions with clasps. The restoration, which I am not able to date or localise, focused on the side cover and on the damages caused by the clasps. New pieces of leather were added to reinforce the damaged parts.

The parchment guard-leaves, one folio in the front and the back of the volume, are too small to be a former soft cover or soft binding of the MTM. The rest

10 Descriptions of these two manuscripts are found in Juste 2015 and in the online catalogue of the BnF. For BnF lat. 7432 see: http://archivesetmanuscrits.bnf.fr/ark:/12148/cc66655v and for BnF lat. 7197 see: http://archivesetmanuscrits.bnf.fr/ark:/12148/cc66378g (last accessed 26 December 2017).

11 Andrist / Canart / Maniaci 2013.

12 A complete digitisation of the manuscript can be consulted at: https://gallica.bnf.fr/ ark:/12148/btv1b90664785 (last accessed 12 October 2019). 
of the codex is made of paper. Several folios have watermarks..$^{13}$ On folios 48, 55 , 58 and on folios 12, 13, 14, 22, 24, 28, 29 and 30 we find two kinds of bull head with a starry stem that can be compared to two ones attested in Fribourg in 1455, respectively: Piccard-Online $75176^{14}$ and, Piccard-Online $74864^{15}$. Some watermarks presenting a coat of arms with three lilies and a crown are attested in Paris around 1456 and 1457-1461 (Briquet ${ }^{16}$ nos 1681 and 1683) respectively on folios 76, 77, 78, 84 and 65, 68, 69, 71, 72, 73. Another watermark of the same family closer to Briquet ${ }^{17}$ no. 1739 attested in Paris in 1458 is present on folios $117,123,125,127,128,129$. A last class of watermark with a crescent surmounted by a six-pointed star, close to Briquet ${ }^{18} 5345$ and attested in Holland between 1419 and 1427, can be seen on fols 91, 94, 95, 97, 98, 99 and 100.

The quire structure can be described as follow:

- Quire 1: fols 2r-21v, 20 folios

In between fols $11 v-12 r$ the parchment used in the binding can be seen. It seems to be of the same provenance as the guard-leaf. Wear of the first and last folio of the quire could be explained by the hypothesis of independent circulation of the quire before binding. Watermark Fribourg 1455.

- Quire 2: fols 22r-35v, 14 folios

In between fol. $28 \mathrm{v}-29 \mathrm{r}$ the parchment used in the binding can be seen. It seems to be of the same provenance as the guard-leaf. One bifolium is added and numbered at fols 22r-23r/31v-33r. Only the second half of it is noted, and a small volvelle is glued on it. Similarly, an added bifolium is inserted fols $23 v-24 r / 33 v-35 r$. It is noted on both half and numbered. Wear of the first and last folio of the quire could be explained by the hypothesis of independent circulation of the quire before binding. Watermark Fribourg 1455

- Quire 3: fols 36r-48v, 13 folios

In between fols $41 \mathrm{v}-42 \mathrm{r}$ the parchment used in the binding can be seen. It seems to be of the same provenance as the guard-leaf. Watermark Fribourg 1455.

13 The following description of the watermark is taken from: http://archiveset manuscrits.bnf.fr/ark:/12148/cc66378g (last accessed 26 December 2017).

14 (last accessed December 26, 2017).

15 (last accessed December 26, 2017).

16 Briquet 1907.

17 Briquet 1907.

18 Briquet 1907. 
- Quire 4: fols 49r-60v, 12 folios

In between fols $54 \mathrm{v}-55 \mathrm{r}$ the parchment used in the binding can be seen. It seems to be of the same provenance as the guard-leaf. Watermark Fribourg 1455.

- Quire 5: fols 61r-74v, 14 folios.

In between fols $67 \mathrm{v}-69 \mathrm{r}$ the parchment used in the binding can be seen. It seems to be of the same provenance as the guard-leaf. Watermark Paris 1457-1461

- $\quad$ Quire 6: fols 75r-84v, 10 folios

In between fols $81 \mathrm{v}-82 \mathrm{r}$ the parchment used in the binding can be seen. It seems to be of the same provenance as the guard-leaf. Watermark Paris 1456

- Quire 7: fols 85r-102v, 18 folios

In between fols $93 \mathrm{v}-94 \mathrm{r}$ the parchment used in the binding can be seen. It seems to be of the same provenance as the guard-leaf. The paper quality is markedly different from the preceding folio. Wear of the first and last folio of the quire could be explained by the hypothesis of independent circulation of the quire before binding. Watermark Holland 1419-1427.

- Quire 8: fols 103r-116v, 14 folios

In between fols $109 v-110$ r the parchment used in the binding can be seen. It seems to be of the same provenance as the guard-leaf. Wear of the first and last folio of the quire could be explained by the hypothesis of independent circulation of the quire before binding.

- Quire 9: fols 117r-129v, 13 folios

In between fols 109v-110r the parchment used in the binding can be seen. It seems to be of the same provenance as the guard-leaf. Wear of the first and last folio of the quire could be explained by the hypothesis of independent circulation of the quire before binding. Watermark Paris 1458.

\section{BnF lat. 7432}

BnF lat. 7432 is a 275 folios manuscript of approximate dimension $125 \times 205$ mm. ${ }^{19}$ The binding is modern on wood board covered with brown leather. Guard-leaves, three folios of multicolour paper in the front and back of the MTM, seems to be from the nineteenth century. Also, a modern numbering of quires indicates that the binding was probably entirely redone in the nineteenth century. Apart from those guard-leaves, the rest of the manuscript is of parch-

19 A complete digitisation of the manuscript can be consulted at: https://gallica.bnf.fr/ ark:/12148/btv1b100202503 (last accessed 12 October 2019). 
ment. Most of the manuscript parchment seems to have the same origin. However, the last quire of the volume is of a different quality, and possibly of a different origin. The quire structure can be described as follows:

- Quire 1: fols 1r-4v, 4 folios

- Quire 2: fols $5 \mathrm{r}-17 \mathrm{v}+14 \mathrm{bis}, 14$ folios

Quire number ' 2 ' can be read on fol.5r. A folio numbered 14 is inserted in between folios 17 and 18.

- Quire 3: fols 18r-33v, 16 folios

- Quire 4: fols 34r-48v, 14 folios

- Quire 5: fols 49r-65v, 17 folios fol. 65 seems to be from parchment of different quality than the rest of the document.

- Quire 6: fols 66r-78v, 13 folios

Again fol. 78 seems to be added to an original 12 folios quire.

- Quire 7: ff 79r-90v, 12 folios

- Quire 9: ff 91r-104v, 14 folios

- Quire 10: ff 105r-117v, 13 folios

fol. 109 is added with its cut second half appearing in between folios 113 and 114 .

- Quire 11: fols 118r-129v, 12 folios

- Quire 12: fols 130r-143v, 14 folios

- Quire 13: fols 144r-159v, 16 folios

Quire number ' 13 ' can be read on fol.144r. F.147r-150v seems to be added to an original 12 folios quire.

- Quire 14: fols 160r-171v, 12 folios Quire number ' 14 ' can be read on fol. 160r

- Quire 15: fols 172r-183v, 12 folios Quire number ' 15 ' can be read on fol. 172r

- Quire 16: fols 184r-198v, 14 folios Quire number ' 16 ' can be read on fol. 184r. fols 184 and 198 seems to be added to an original 12 folios quire.

- Quire 17: fols 199r-210v, 12 folios Quire number '17' can be read on fol. 199r

- Quire 18: fols 211r-222v, 12 folios Quire number ' 18 ' can be read on fol. 211r

- Quire 19: fols 223r-237v 15 folios fols. 223, 237, and a non-numbered half folio in between $226 \mathrm{v}-227 \mathrm{r}$ seems to be added to an original 12 folio quires. 
- Quire 20: fols 238r-251v, 14 folios

Quire number '20' can be read on fol. 238r

- Quire 21: fols 252r-263v, 12 folios

Quire number '21' can be read on fol. 252r

- Quire 22: fols 264r-269v, 6 folios

Quire number '22' can be read on fol. 264r

- Quire 23: fols 270r-275v, 6 folios

Quire number '23' can be read on fol. 270r. Parchment of a different quality

This first level of description already shows interesting contrasts between the two manuscripts. 7432 is more compact than 7197 but has twice as much folios. The modern restoration of the binding of 7432 makes a comparison between bindings of the two manuscripts non-pertinent for the study of how late medieval actors produced and interacted with these documents.

The material from which the documents were produced is more interesting for our purposes. 7197 is built from an assemblage of papers from various origins. Those from Paris are contemporaneous with the presence of Conrad Heingarter there, while those from Fribourg, which are a little older, point to his native region. The older paper from Holland does not coincide with Heingarter's flourishing time. On the other hand, 7432 is built mainly from a homogenous source of good quality parchment (apart from the final quire).

The two manuscripts differ in the way the quires were structured. The quire organisation of 7432 is complex, but it is apparent that an initial set of 12 folios quires had been prepared. Supplementary folios were added to some of these quires. None of the quires from 7432 shows traces of an independent circulation before binding. This is a very important and marked contrast with 7197 . In the 7197, at least 5 quires from the 9 that compose the MTM show marks of independent circulation before binding. The number of folio per quire is irregular, and I cannot discern any fundamental quire size. The number of cases in which the hypothesis of added folia to an initial quire can be made is also much lower in the case of 7197.

These contrasts are already informative and allow the formulation of a first series of hypotheses about the different production processes from which these manuscripts were derived. In 7197, the diversity of papers from different periods and regions indicate that the production of the manuscript took time, probably a number of years. This hypothesis is reinforced by the randomness of the quire composition and the possibility of an independent circulation of half of the quires composing the manuscript. This allows the hypothesis that the MTM is an a posteriori product of a process which was not focused mainly on the manu- 
script production but around other kind of objectives. 7432 is a different case insofar as a sufficient amount of rather expensive material had been prepared. The variability of the quire composition (apart from the last quire) can be reduced to a base set of 12 -folio quires. This points to a more carefully planned production of the manuscript and the codex in itself was probably the initial objective of the actors which produced it.

\section{Marks, layout, hands and decorations}

\section{BnF lat. 7197}

A stamp from the royal library from before 1735 is on the second folio, which, ${ }^{20}$ in addition to a mention of the document in BnF lat. 9363, indicates that Colbert acquired the document in 1675 (Colbert 1499, fol. 2r) from Claude Hardy. It entered the royal library in 1732 (Regius 5864.3, fol. 2r) at the same time as BnF lat. 7295A, another manuscript produced by Conrad Heingarter. ${ }^{21}$ Astronomical manuscripts often feature different dates. In this case the various dates are as follows:

- fol. $1 \mathrm{v}$, on the guard leaf the years 1340-1380 are mentioned

- fol. 21r, 'anno 1420/ anno 1448/ anno 1456/ anno 1504'

- fol. 61r, '... anno 1473 currenti ... ad annum 1498 currentem...'

- fol. 67v, 'usque ad annum 1498 completum ultimo die decembris'

- fol. 68v, 'et sic est finis anno 1446' This mention is crossed out in the manuscript

- fol. 102v 'item licet 1456 non sit completum'

- fol. 103v 'Item anno 1456 ward...'

- fol. 104r, 'radix 1456 completus ultima die decembris..'

- fol. 113v, computation is made for the year 1446

Both ink (e.g. fols 3-14) and dry point (e.g. fols 15-16) were used in ruling the various quires of $7197 .{ }^{22}$ This diversity also corresponds to a diversity in layout and text distribution in the quires:

20 Josserand / Bruno 1960, $\mathrm{n}^{\circ} 5$.

21 From BnF online catalogue: http://archivesetmanuscrits.bnf.fr/ark:/12148/cc66378g (last accessed 26 December 2017).

22 From BnF online catalogue: http://archivesetmanuscrits.bnf.fr/ark:/12148/cc66378g (last accessed 26 December 2017). 
- Quire 1: fols 2r-21v

fols $2 \mathrm{r}-2 \mathrm{v} 2$, two columns

fols $3 \mathrm{r}-14 \mathrm{v}$, one column, large margin with comments (idem fols $17 \mathrm{r}-20 \mathrm{v}$ )

fols $15 \mathrm{r}-16 \mathrm{v}$, one column, small inferior margin with comments

fols $17 \mathrm{r}-20 \mathrm{v}$, idem fols $3 \mathrm{r}-14 \mathrm{v}$

fols $21 \mathrm{r}-21 \mathrm{v}$, specific (added?) ruling for the table

- Quire 2: fols 22r-35v

fols $22 \mathrm{r}-35 \mathrm{v}$, uniform ruling on this quire. Large inferior margin with comments.

One column. The size of the text letters' become smaller as the end of the quire is nearer.

- $\quad$ Quire 3-6: fols 36r-...-84v

fols $36 \mathrm{r}-84 \mathrm{v}$, Ruling close to that of quire 2 but with a smaller inferior margin with comments. One column except for fol. 66r where the text is in two columns.

- Quire 7: fols 85r-102v

fols $85 \mathrm{r}-102 \mathrm{v}$, Specific ruling for the tables. Tables on every page apart from $102 \mathrm{v}$ showing prose text.

- Quire 8: fols 103r-116v

fols $103 \mathrm{r}-116 \mathrm{v}$, uniform ruling but diversely treated in term of writing repartition with respect to table or prose content. Prose content is in one column. fol. $116 \mathrm{v}$ as an empty ruling prepared for a table.

- Quire 9: fols 117r-129v

fols $117 \mathrm{r}-129 \mathrm{v}$, uniform ruling but text repartition from one to four columns with sometimes changes on the same page (e.g. fol. 118r). Most of the pages are treated with two columns. The size of the script becomes smaller as the end of the quire is nearer.

The manuscript is mainly by one cursive hand, which can be attributed to Conrad Heingarter thanks to the colophon Explicit tractatus spere materialis per manus Conradi Heingarter (fol. 50r). Conrad's hand is responsible for all quires' main text, with the exception of nos 7 and 9, which are written by two different unknown hands. Conrad Heingarter has also annotated quire 7 on fol. 102v and quire 9 on fol. 117r. The hand marking the guard-leaves is also unknown.

Decoration is of low quality in the manuscript. The few decorative elements are rather poorly executed by Conrad Heingarter (e.g. a crucifix on fol. 82v). In some instances, pointing hands are found in the margins (e.g. fols 53r, 63v, 64r). Apart from this, there are no other noteworthy decorative elements in the manuscript.

Devices to enhance the readability of the document are also very rudimentary. Apart from a few a-posteriori attempts to use red ink in the last quire's numerical 
tables, every page is written with brown or black ink. Most of the initials had not been finalised (e.g. fol. 30r). Texts may have a somewhat distinguished title (e.g. fol. 30r), but this is not always the case. Sometime a line is skipped to mark a chapter or a paragraph change but this is not systematic. Conrad Heingarter's hand on fol. 117r added some sort of general title for quire 9.

The decoration and text-enhancing marks change from one hand to another, from one quire to another, and even within the same quire, without exhibiting any discernible coherent system.

\section{BnF lat. 7432}

The two royal library stamps on folios $5 \mathrm{v}$ and $275 \mathrm{v}$ are different from those found on the second folio of the 7197. On fol. 5r two previous shelfmarks: 'Reginus 6033' and 'Colbertinus 6089' are also found. Three dates appear on fol. 148v (1477), fol. 207v (1468), and fol. 259r (1480). Jean II de Bourbon is repeatedly mentioned as a dedicatee (fol. 3v-4r; fol. 125v-126r, fol. 135r, fol. 148v, fol. 222r, fol. 223r, fol. 259r). Finally, folio 223r-v contains a mention of the Castle of Belleperche (in the department of Allier): Stelle verificate ad eram Iohannis Borboni ducis et ad orizontem Bellepertice. ${ }^{23}$

Ruling is marked with ink. Pages are essentially prepared for a main text surrounded with large margins to allow for the insertion of a marginal text written in a smaller module. This marginal text is not always supplied. Some texts and tables are copied with narrower margin and thus less room for commentary. The quire repartition of these different situations is telling.

- Quire 1: fols 1r-4v

fols $1 \mathrm{r}-3 \mathrm{v}$, one main text small margin, cursive hand

fols $4 \mathrm{r}-\mathrm{v}$, one main text with large margin book-hand, marginal text cursive hand

- Quire 2 fols $5 \mathrm{r}-17 \mathrm{v}$

fols $5 \mathrm{r}-17 \mathrm{r}$, one main text large margin book hand, marginal text cursive hand fols $17 \mathrm{v}$, one main text small margin cursive hand

- Quire 3: fols 18r-33v

fols $18 \mathrm{r}-24 \mathrm{v}$, one main text large margin book hand, marginal text cursive hand

fols $25 \mathrm{r}-\mathrm{v}$, one main text small margin cursive hand

23 Juste 2015. 
fols $26 \mathrm{r}-32 \mathrm{v}$, one main text large margin book hand, marginal text cursive hand

fols $33 \mathrm{r}-\mathrm{v}$, one main text small margin cursive hand

- Quire 4: fols 34r-48v

fols $34 \mathrm{r}-40 \mathrm{v}$, one main text large margin book hand, marginal text cursive hand

fols $41 \mathrm{r}-\mathrm{v}$, one main text small margin cursive hand

fols $42 \mathrm{r}-45 \mathrm{v}$, one main text large margin book hand, marginal text cursive hand

fols $46 \mathrm{r}-\mathrm{v}$, one main text small margin cursive hand

fols $47 \mathrm{r}-48 \mathrm{v}$, one main text large margin book hand, marginal text cursive hand

- Quire 5: fols 49r-65v

fols 49r-50v, one main text large margin book hand, marginal text cursive hand

fols51r-52v, one main text small margin cursive hand

fols $53 \mathrm{r}-59 \mathrm{v}$, one main text large margin book hand, marginal text cursive hand

fols $60 \mathrm{r}-61 \mathrm{v}$, one main text small margin cursive hand

fols $62 \mathrm{r}-64 \mathrm{v}$, one main text large margin book hand, marginal text cursive hand

fols $65 \mathrm{r}-\mathrm{v}$, one main text small margin cursive hand

- Quire 6: fols 66r-78v

fols $66 \mathrm{r}-77 \mathrm{v}$, one main text large margin book hand, marginal text cursive hand

fols $78 \mathrm{r}-\mathrm{v}$, one main text small margin cursive hand

- Quire 7: fols 79r-90v

fols $79 \mathrm{r}-90 \mathrm{v}$, one main text large margin book hand, marginal text cursive hand

- $\quad$ Quire 9: fols 91r-104v

fols $91 \mathrm{r}-\mathrm{v}$, one main text small margin cursive hand

fols $92 \mathrm{r}-103 \mathrm{v}$, one main text large margin book hand, marginal text cursive hand

fols 104r-v, one main text small margin cursive hand

- Quire 10: fols 105r-117v

fols $105 \mathrm{r}-108 \mathrm{v}$, one main text large margin book hand, marginal text cursive hand

fols 109r-v, one main text small margin cursive hand 
fols $110 \mathrm{r}-117 \mathrm{v}$, one main text large margin book hand, marginal text cursive hand

- Quire 11: fols 118r-129v

fols 118r-126r, one main text large margin book hand, marginal text cursive hand

fols $126 \mathrm{v}-129 \mathrm{v}$, one main text large margin book hand

- Quire 12: fols 130r-143v

fols 130r-134r, one main text large margin book hand

fols $134 \mathrm{v}-135 \mathrm{v}$, one main text small margin cursive hand

fols $136 \mathrm{r}-141 \mathrm{v}$, one main text large margin book hand, marginal text cursive hand

fols $142 \mathrm{r}-143 \mathrm{v}$, one main text small margin cursive hand

- Quire 13: fols 144r-159v

fols $144 \mathrm{r}-146 \mathrm{v}$, one main text large margin book hand, marginal text cursive hand

fols $147 \mathrm{r}-150 \mathrm{v}$, one main text small margin cursive hand

fols 151r, one main text large margin book hand, marginal text cursive hand

fols 151v-156v, one main text large margin book hand

fols $157 \mathrm{r}-159 \mathrm{v}$, one main text small margin cursive hand

- Quire 14-15: fols 160r-...-183v

fols $160 \mathrm{r}-183 \mathrm{v}$, one main text large margin book hand

- Quire 16: fols 184r-198v

fols $184 \mathrm{r}-\mathrm{v}$, one main text small margin cursive hand

fols $185 \mathrm{r}-193 \mathrm{v}$, one main text large margin book hand

fols $194 \mathrm{r}-197 \mathrm{v}$, one main text large margin book hand, marginal text cursive hand

fol. 198r-v, one main text small margin cursive hand

- Quire 17: fols 199r-210v

fols 199r-210v, one main text large margin book hand

- Quire 18: fols 211r-222v

fols $211 \mathrm{r}-218 \mathrm{v}$, one main text large margin book hand

fols $219 \mathrm{r}-221 \mathrm{v}$, one main text large margin book hand, marginal text cursive hand

fols $222 \mathrm{r}-\mathrm{v}$, one main text small margin cursive hand

- Quire 19: fols 223r-237v, 15 folios

fols $223 \mathrm{r}-\mathrm{v}$, one main text small margin cursive hand

fols 224r-236v, one main text small margin book hand

fols $237 \mathrm{r}-\mathrm{v}$, one main text small margin cursive hand 
- $\quad$ Quire 20-21: fols 238r-...-263v

fols $238 \mathrm{r}-263 \mathrm{v}$, one main text large margin book hand

- Quire 22: fols 264r-269v

fols $264 \mathrm{r}-269 \mathrm{v}$, one main text small margin book hand. The copy seems to be interrupted abruptly before the work was finished on fol. 268v. F.269r-v are left blank

- Quire 23: fols 270r-275v

fols $270 r-275 v$ one main text large margin. Different ruling and different hand than the rest of the manuscript.

The marginal cursive hand of the first 22 quires is that of Conrad Heingarter. It is difficult to identify the book hand of these first 22 quires. The last quire is from a different hand.

7432 shows elaborate decorative elements, which are closely related to the main text in the large margin layout. In these situations, the main text of most pages includes many illuminations, place holders at the end of lines, and several decorated initials, all of which are beautifully executed with lapis lazuli, gold, red, green and vegetal motifs. This situation is generally true except for quire 22 where no decoration is found, while the space for the initials was reserved during the copy of the main text. Several technical diagrams are also illuminated with the same kind of motifs:

- fol. 212r, nodes of the moon

- fol. 214r, superior planets theory

- fol. 217r, inferior planets theory

- fol. $218 \mathrm{v}$, planet retrogradation

Finally, the manuscript shows an impressive iconographic programme, with eleven very high-quality miniatures:

- fol. 4r, Ptolemy (?) in a representation of the cosmos

- fol. 66r, Ptolemy (?) with four different persons representing different parts of the court society

- fol. 103v, Ptolemy (?) with different persons, including the king around the theme of justice

- fol. 129v, a child standing on his feet, miniature inside a horoscope

- fol.131r, the same child, seated, miniature inside a horoscope

- fol. 134v, Ptolemy (?) taking the king's pulse and pointing at the moon

- fol. 151v, Messahalah (?) in a representation of the cosmos

- fol.160r, scene of public lecture, the orator is pointing at the sun and the stars

- fol. 209r, geometrical representation of the cosmos 
- fol. 224r, geometrical representation of a moon eclipse

- fol. 238v, a young child is learning astronomy (?) with a book opened in front of him. Several adults of different conditions are around him and there is a depiction of a starry sky outside the room.

Their institutional marks suggest that the two manuscripts have quite similar conservation histories. Possibly, they reached Colbert collection's following different paths. The mention of dates and places is interesting as the range of dates proposed by 7432 is much narrower than that of 7197 . This corresponds to the contrast drawn from the material analysis. 7432 shows a mostly uniform supply of high-quality parchment and a small range of dates. 7197 shows a large range of dates and a diversified supply of paper from various origins and dates. Astronomy is a science of time. Computations of dates for specific events, or reversely computation of an astral configuration at a given date, are central to the discipline. In the case of 7197, the dates roughly correspond to what the watermark attests regarding the manuscript's production period. However, we can see that explicitly inscribed dates present a greater time range. The range of inscribed dates corresponds to years mentioned directly in astronomical tables or to computations present in the manuscript as marginal annotations or as examples provided in procedural texts. In the case of 7432, the smaller range of dates is also explained by a characteristic of the astronomical practice related to the production of the manuscript: the wish to adapt its content (star tables, epoch, horoscopes) to a very specific context related to the dedicatee.

The comparison of the information gathered from the physical analysis of the manuscripts and that of the rulings, layout and hands is very informative. The most striking aspect of 7197 is the very strong correlation between those quires that show marks of independent circulation and those which show a script becoming smaller towards the end of the quire (quires 2 and 9). Another element pointing in the direction of an independent circulation of various units before binding is the page title of fol. 117r, isolating the last quire as an independent unit. The similarity of 7197's quires 3 to 6 in term of layout and ruling organisation might indicate that they formed a coherent unit at some point. That is consistent with the hypothesis that Conrad Heingarter compiled the manuscript's quires in a gradually planned way for as long as new interests appeared to him. This, together with the generally unsystematic character of 7197 ruling and layout organisation, confirms the general impression that he gathered a posteriori quires that were produced with a loosely defined a priori intention of making a formally unitary codex. 
MS 7432 is also complex with respect to layout. The most striking aspect is the repartition of the marginal text and the decoration with respect to the quire organisation. The case of unfinished quire 22 shows that the main text was first copied in a book hand. The presence of several portions of the manuscript with a decorated main text and no marginal text shows that the main text decoration was probably made before the addition of a marginal text. When the marginal text was added, its length was such that on several occasions folios were added to the initial quires so it could be copied in correspondence with the main text (e.g. quire 9). Also, it appears that in some cases no marginal text was really envisioned to complement the main text. Notably, this situation applies to most of quire 19, where only the main text is copied in a smaller margin than the one used when a marginal text had originally been planned. This simple scenario accounts quite well for the structure of 7432. It also shows that a specific intellectual practice, i.e. the production of a secondary text in relation to the main one, is linked to the production of the manuscript.

The contrast between the decorations of the two manuscripts is probably the most striking. It points in the same direction as the conclusion of the preceding part: a different balance between the process of producing the document and the astronomical practices related to it.

\section{Manuscript contents}

\section{BnF lat. 7197}

In contrast to its underdeveloped decoration, MS 7197 has 16 folios with diagrams. In some cases, these diagrams show that they were drawn directly on bound quires. For instance, on folios $16 \mathrm{v}$ and $17 \mathrm{r}$ some of the construction marks of the diagram extend from one page to the next. Another clue is related to the use of a compass to draw circles. In the case of folios 51r, 52r, 53v, 55v, 57v the compass tip made a hole on the neighbouring folios. Some of these diagrams belong directly to the main text, while the others are integrated in marginal annotations. Another striking point is the diversity of the diagrams. Some are very precisely executed with rulers and compass while others are drawn in haste without geometrical instruments. They cover a range of topics from arithmetic (left margin of fol. $7 \mathrm{r}$ ) to cosmology ( $\mathrm{T}-\mathrm{O}$ world map of fol. 38r). The arithmetical scale of fol. 31r, allowing for a conversion between sexagesimal and ordinary fraction, is particularly interesting. The series of diagrams on fol. $79 \mathrm{r}-\mathrm{v}$ combine theory of proportion and geometry and are also interesting from a history of mathematics perspective. 
Many of the astronomical technical drawings of 7197 are directly related to the Theorica planetarum Gerardi. These diagrams are notable because they bear texts that enrich the description of the astronomical properties illustrated (Fig. 1).

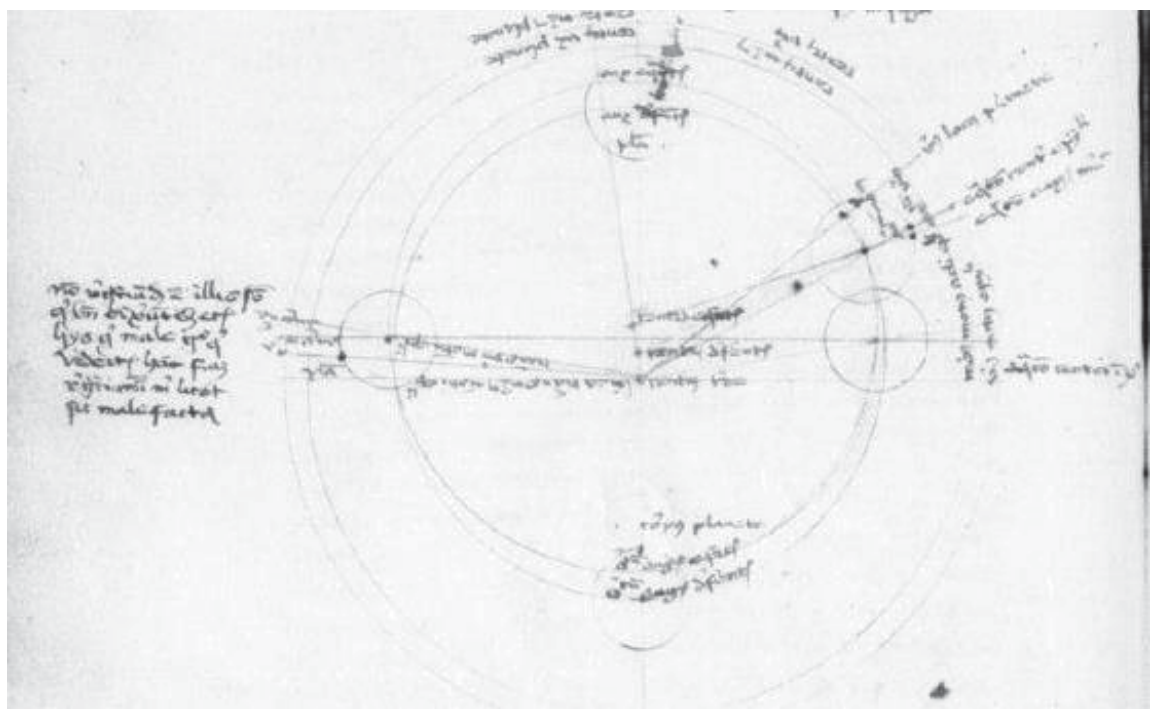

Fig. 1: Illustration of the Theorica planetarum Gerardi by Conrad Heingarter; BnF lat. 7197, fol. $53 \mathrm{v}$ (detail), (C) BnF Gallica

Essentially, the astronomical tables in 7197 are gathered in two distinct sets. The first set, on quire 7, concerns calendrical computation and is related to Prague and the year 1400 . The second set, on quire 8 , concerns planetary motion (including the sun and moon) in the Alfonsine tradition. In this second set, mean motions are given in calendrical form, not in the full sexagesimal version described in John of Saxony canons of 1327. They are given with a radix for 1444. The equations are given using sign of $30^{\circ}$ and with a step of $5^{\circ}$ between the arguments. Overall, this second set of tables proposes a compact and not very precise version of the Parisian Alfonsine tables. A number of arithmetical tables can also be found in 7197. In contrast to astronomical tables, which appear in sets, these arithmetical tables are spread through the document. They can be related to fractions (fol. 31v) or can be very elementary like the multiplication table found on fol.14v. Some tabular layouts display the execution of a multiplication or other arithmetical procedures (e.g. fol. 35r with the label figura multiplicationis). This kind of content is in the margin between diagrams and tables. 
The diagrams and tables of 7197 reflect the textual content of the manuscript. Thus, arithmetic and astronomy are the two main themes of the document. I have already mentioned that the 1327 canons to the Alfonsine tables by John of Saxony are present in 7197, as well as a version of the Alfonsine tables. It is interesting to note that John of Saxony's canons cannot be used with the versions of the Alfonsine tables present in the manuscript. However, in terms of astronomical content, both cover the same type of phenomenon: planetary motions. The manuscript also contains the Theorica planetarum Gerardi, that is, the traditional planetary theory treatise of the period. Astrology has a very small part in this manuscript with only one identified text on fol. 38r. With respect to arithmetic, the presence of Sacrobosco's Algorismus as an opening text is emblematic of how the faculty of art teaches the discipline. The manuscript also has much more advanced text on fractions, proportion theory and algebra. It is noteworthy that, while the manuscript is mainly written in Latin, an arithmetical text on fols $9 \mathrm{r}-14 \mathrm{v}$ is in German. In addition, a classification of sciences and a Grammatica by Hugh of St Victor reflects some interests in more literary and philosophical topics. This type of content reflects the arts faculty's teaching with quite advanced texts in astronomy and arithmetic. It is also interesting to note that a significant number of small texts, or parts of texts, which are very difficult to identify with precision, are present in the manuscript (e.g. the small fraction algorism on fols 30r-31v, or the 7 lines of text on astrology on fol. 38r). This creates gaps, in some cases of several folios, in the textual content of the manuscript (e.g. fols $17 \mathrm{r}-20 \mathrm{v}$ or $22 \mathrm{r}-29 \mathrm{v}$ are not empty but are inscribed with non-identified texts).

The following detailed quire-by-quire list illustrates the repartition of the contents:

- Quire 1: (fols 2r-21v)

fols 3r-8r, Algorismus, Sacrobosco

fols $9 \mathrm{r}-14 \mathrm{v}$, Arithmetical treatise German and Latin, Arithmetical diagram on fol. $7 \mathrm{r}$

fols 15r-16v, Turquetum, Franco de Polonis, Astronomical diagrams unfinished on fol.16r-v

fol. 21r-v, calendrical tables (fragment)

- Quire 2: (fols 22r-35v)

fols 30r-31r, fraction algorism, fraction conversion scale diagram fol. 31r

fols 31r-..., Algorismus de minutiis, Jean de Lignères

- Quire 3: (fols 36r-48v)

fols ...-36v, Algorismus de minutiis, Jean de Lignères

fols 36v-38r, Algorismus linealis 
fol. 38r, De dominio planetarym in nativitatibus puerorum, T-O map diagram fols 39r-..., De spharea, Sacrobosco, cosmological diagram on fol. 39r

- Quire 4: (fols 49r-60v)

fols ...-50r, De spharea, Sacrobosco

fols $51 \mathrm{r}-57 \mathrm{v}$, Theorica planetarum Gerardi, theory of the sun diagram on fol. 51r, theory of the moon diagram on fol. 52r, theory of Venus and superior planet on fol. 53v, theory of Mercury on fol. 55r, Mercury diagram on fol. $55 \mathrm{v}$, retrogradation diagram on fol. $57 \mathrm{v}$

fols 58v-..., Tempus est mensura motus..., John of Saxony

- Quire 5: (fols 61r-74v)

fols ... $-68 \mathrm{v}$, Tempus est mensura motus..., John of Saxony

fols $68 \mathrm{v}-71 \mathrm{r}$, Oratio pro Marcello, Cicero

fols 71r-73v, Oratio pro Ligario, Cicero

- Quire 6: (fols 75r-84v)

fols $74 \mathrm{r}-79 \mathrm{v}$, Algorsimus proportionum, Oresme, Proportion theory diagram on fols $74 \mathrm{v}, 76 \mathrm{r}, 79 \mathrm{r}, 79 \mathrm{v}$

fols $80 \mathrm{r}-81 \mathrm{r}$, Algorismus proportionibus

fols 81r-82r, arithmetical treatise, attributed to Jean des Murs

fols 82v-84r, Divisiones Sacrae Scirpturae

- Quire 7: (fols 85r-102v)

fols 85r-102r, Calendrical tables (Prague 1400)

- Quire 8: (fols 103r-116v)

fols 104r-112r, Alfonsine tables (1444)

fol. 112v, Tractatus de astronomia (syzygies?)

fols 114r-115r, Tractatus de quadrante

fols 116r, Alfonsine tables (fragment)

- Quire 9: (fols 117r-129v)

fol. 118r, Disdascalicon, Hugh of St Victor

fols 118r-129v, Grammatica, Hugh of St Victor

In contrast to what I noted above on the complex relation between astronomical tables and texts, the relation between diagrams and texts is quite different: all diagrams are in direct relation to the manuscript text in their closest proximity. The most significant series in this respect are the astronomical diagrams related to the Theorica planetarum Gerardi on fols $51 \mathrm{r}-57 \mathrm{v}$ and the Proportion theory diagram related to Oresme's treatise on fols $74 \mathrm{v}-79 \mathrm{v}$. In the analysis of the ruling and layout of 7197, a connection between quires 3 to 6 was noted. The sequence of the contents highlights another link between the quires 2 to 5 . Moreover, the ruling and layout organisation of quire 2 is very close to that of quires 3 to 6 . 
Thus, it is likely that the unit formed by quire 2 to 6 formed an autonomous circulation unit at some point in the history of the manuscript. The fact that quire 2 shows marks of independent circulation would suggest that this unit was probably not bound or that quire 2 was first inscribed without Jean de Lignières' text. The variety of papers forming this unit reinforces the hypothesis of a progressive constitution. Quire 1, 7, 8 and 9 are autonomous in terms of intellectual content, and each could have been an independent circulation unit at some point in the manuscript's history.

\section{BnF lat. 7432}

Ten pages of 7432 are inscribed with one diagram each. These diagrams show two kinds of content: two horoscope diagrams and eight astronomical diagrams. Among those astronomical diagrams, six are directly related to the copy of the Theorica planetarum Gerardi. A detailed and technical comparison between that series of diagrams and the corresponding ones in 7197 is beyond the scope of this contribution but would certainly be fruitful. The two series show strong similarities but also interesting contrasts: the diagrams of 7432 are more schematic and, most remarkably, do not insert as much textual content.

It is more important for our present purposes to note another aspect of the technical diagrams of 7432 (Fig. 2). Some of these diagrams are purely geometrical and are not illuminated or decorated in any way (e.g. fols 209v, 210v). However some diagrams are illuminated (fols 212r, fols 214r, fol. 217r and fol. $218 \mathrm{v}$ ), others are decorated with a miniature (fol. 129v, fol. 131r), while finally two technical diagrams were completely transformed into miniatures (fol. 209r, fol. 224r, Figs 2-3). This suggests that the miniaturist(s?) somehow collaborated with Conrad Heingarter, or whoever produced the technical diagrams, using them as the initial drawing for their painting. 


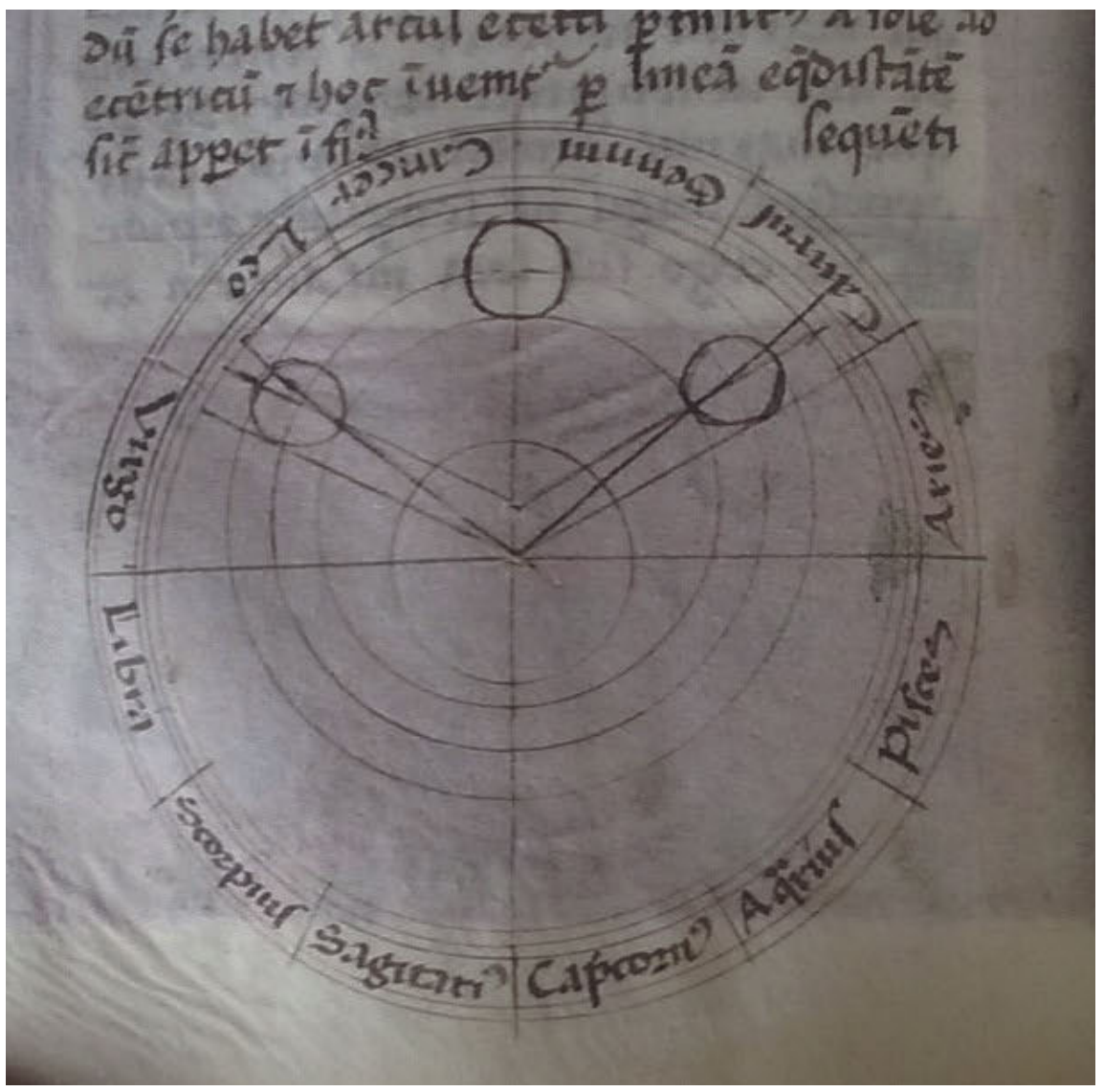

Fig. 2: Illustration of the Theorica planetarum Gerardi by Conrad Heingarter, BnF lat. 7432 fols $209 \mathrm{v}$ (detail, diagonal about $5 \mathrm{~cm}$ ) $\odot$ BnF Gallica

Tables in 7432 are essentially gathered in the final part of the manuscript from fols $239 \mathrm{r}$ to 263v. This ensemble is actually formed of two distinct sets. From fols $239 \mathrm{r}$ to $258 \mathrm{v}$ a version of the Alfonsine tables is found. Then, after two small texts on an astrological topic, a set of astrological tables is found from fol. $259 \mathrm{v}$ to fol. 263v. A few other tables are found isolated in the document: on fol. 159r$\mathrm{v}$ a geographical table (incomplete), on fol. $184 \mathrm{r}-\mathrm{v}$ astrological tables, on fol. $187 \mathrm{r}-\mathrm{v}$ a star table (empty) and on $223 \mathrm{r}-\mathrm{v}$ a star table. The folio with incomplete and empty tables shows us that the general layout and headings of a given table were prepared and copied before the actual numerical data of the table. The version of the Alfonsine tables attested in 7432 begins with a set of chronologi- 
cal tables. Tables for the motion of the eighth sphere follow. Radices and mean motion tables come after. Mean motion tables are presented in their full sexagesimal version. The set is closed with the explicit finiunt tabule illustrissimi regis Alfonsiis after a set of equation tables on fol. 252r. After this explicit other astronomical tables are copied in the same kind of layout. Thus, while being set outside from the authority of the king Alfonso X, they are presented as belonging to the same set of tables. In this 'auxiliary' or 'complementary' set we find trigonometrical tables (right and oblique ascension), equation of time table, table related to syzygies computation and latitude tables for the moon and planets.

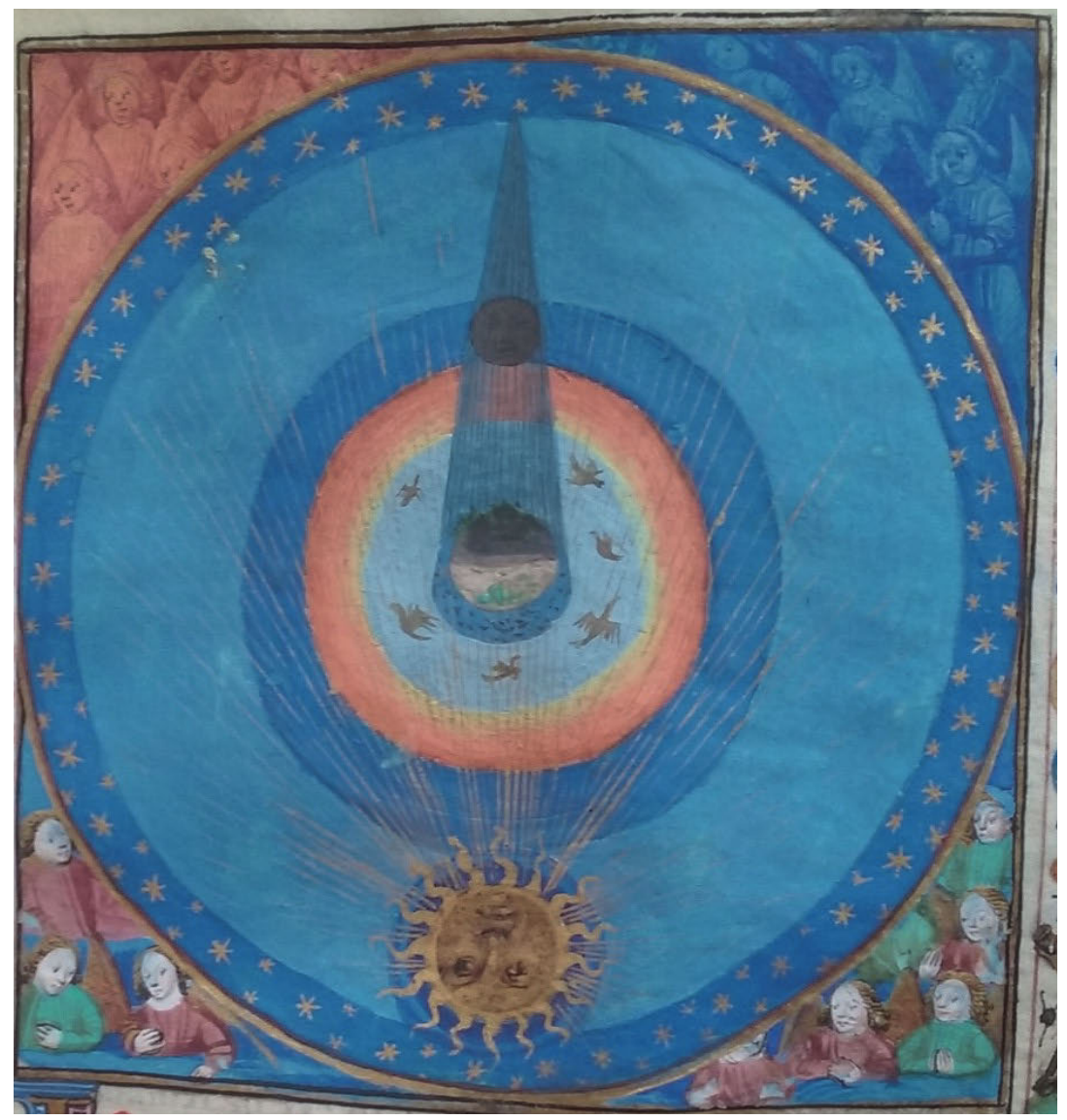

Fig. 3: Miniature illustrating eclipses theory in BnF lat. 7432, fol. $224 \mathrm{r}$ (detail) @ BnF Gallica 
The main themes of 7432 are coherent with those of its diagrams and tables. The manuscript content mainly concerns astrology and astronomy. The major texts of the astrological discipline are present and commented in the manuscript: Ptolemy Quadripartitum and Pseudo-Ptolemy Centiloquium, Messahalah Vir sapiens dominabitur astris and Alcabitius Introductorius. They are presented mainly at the beginning of the manuscript. A section on mathematical astronomy then begins with John of Saxony's canons of 1327, the Theorica planetarum Gerardi and the Alfonsine tables. In this case, the canons perfectly match the version of the Alfonsine tables present in the document. The manuscript is then concluded with smaller texts related to astrology but also connected to other topics (with, for instance, a small text on astrological images) or texts related to medical astrology (with an Astronomia Ypocratis). Small texts related to meteorology are also found in the manuscript. Thus, the intellectual project behind the manuscript is clear: it demonstrates the mastery of Conrad Heingarter on the fundamental concepts of astrology, on its mathematical astronomy tools and finally on its relations to connected disciplines, such as meteorology, medical astrology and astrological images. The iconographic program of MS $7432 \mathrm{com}-$ plements the general intellectual intention behind the production of the manuscript. Miniatures explicitly point to some aspects: for instance, the relation between astrology and medicine. Miniatures also nicely complement the content of the manuscript by pointing to astrology's scope of application in relation to courtly activities and the king's duties. A miniature showing a master giving a class introduces the manuscript's mathematical astronomy section. The necessity of studying and thus Conrad Heingarter's competence is also illustrated by the last miniature.

The general distribution of this material in the manuscript is as follows:

- Quire 1: fols 1r-4v

fol 1r, De vita Ptholomei

fols $1 \mathrm{v}-3 \mathrm{v}$, Table of content

fols 4r-..., Quadripartitum, Ptolemy

- $\quad$ Quire 2-12: fols 5r-...-143v

fols ...-134r, Quadripartitum, Ptolemy. Two horoscope diagrams on fol. 129v and $131 \mathrm{r}$

fols 134v-..., Centiloquium, Pseudo-Ptolemy

- Quire 13: fols 144r-159v

fols ...-146r, Centiloquium, pseudo-Ptolemy

fols $146 \mathrm{v}-148 \mathrm{v}$, De cometis, pseudo-Ptolemy

fols 149r-151r, small meteorological texts

fols 151v-156v, Epistola de rebus eclipsium, Messahallah 
fols 157r-159r, Vir sapiens dominabitur astris, Messahallah

fols 159v-..., Introductorius, Alcabitius. Fol. 159r-v: a geographical table (incomplete)

- Quire 14-17: fols 160r-...-210v

fols ...-208v, Introductorius, Alcabitius. Fol. 184r-v: astrological tables, and fol. $187 \mathrm{r}-\mathrm{v}$ a star table (empty)

fols 209r-..., Theorica planetarum Gerardi. Fol. 209r: cosmological diagram turned into a miniature, fol. 209v and fol. 210v, sun theory and moon theory diagrams.

- Quire 16-18: fols 211r-...-222v.

fols ...-222r, Theorica planetarum Gerardi. F. 212r, fol. 214r, fol. 217r and fol. $218 \mathrm{v}$ planetary theory diagrams, illuminated.

- Quire 19: fols 223r-237v 15 folios

fols $223 \mathrm{r}-\mathrm{v}$, Star table

fols 224r-236v, Tempus est mensura motus..., John of Saxony. Fol. 224r eclipse diagram transformed into a miniature.

fols $237 \mathrm{r}-$..., De statione planetarum et retrogradatione

- Quire 20: fols 238r-251v

fols ...-238r, De statione planetarum et retrogradatione

fols 239r-251v, Tabule illustrissimi regis Alfonsii

- Quire 21: fols 252r-263v

fols $252 \mathrm{r}-258 \mathrm{v}$, Other astronomical tables

fols 259r, Astrological text

fols $259 \mathrm{v}-263 \mathrm{v}$, Astrological tables

- Quire 22: fols 264r-269v

fols 264r-266r, Astronomia Ypocratis

fols 266v-268r, Tractatus de pronosticis et componendis

fols $268 \mathrm{v}$, De scientia pestilentie

- Quire 23: fols 270r-275v.

fols 270r-275v Greek alphabet, prayers in Greek with interlinear Latin translation.

The most striking features of this distribution are the two long blocks of quires forming most of the manuscript. The first block, containing more than 200 folios, extends from quire 1 to quire 18. The second is formed of quire 19 and 20. Then the three remaining quires are autonomous in terms of content. The first long block is mainly concerned with astrology. The second is concerned with mathematical astronomy, also with a part of quire 21, and the last two quires with short texts on various topics related to astrology. These impressive blocks 
of quires point in the same general direction as other aspects described before: that of an organised, even if quite complex, production process.

The analysis of the manuscripts' content confirms and illustrates more precisely the hypotheses which were drawn from the descriptions of the documents' first two dimensions. The content distribution's in quires and the links it shows between some of the quires corroborate the fact that the production of 7432 had consistently been organised with a rather precise vision of what would be the structure of the final codex (except probably for the last part of the production process and the inclusion of commentary texts to the astrological treatises) whereas the production of 7197 was probably less organised. Another feature of comparison concerns the intellectual coherence of the two documents. 7197's intellectual structure comes directly from the teaching context of the art faculty and shows Conrad as a student for topics of arithmetic and mathematical astronomy. ${ }^{24}$ The intellectual coherence comes from Conrad Heingarter's reaction to a specific intellectual milieu. By contrast, the intellectual structure of 7432 was planned to deliver a specific message to the dedicatee of the manuscript with respect to the importance of Conrad Heingarter's competence in astrology and mathematical astronomy. In that case Conrad Heingarter probably had more initiative in his choice of texts even though he is certainly constrained by the standard of the discipline.

\section{Conclusion}

Among the different clues offered by the manuscripts described in this contribution, the quire structure is certainly central in order to understand the production process of the manuscript. Often, by relating the distribution of other aspects of the manuscript to the quire structure, the structural continuities and discontinuities are made apparent, and can be evaluated. Evaluating the meaning of these continuities and discontinuities leads us to the following contrasted description and summary of the production process.

BnF lat. 7197 appears as the result of a process where a student in the art faculty, with a specific interest in arithmetic and mathematical astronomy, collects, probably during the time of his studies, texts and parts of texts related to these

$24 \mathrm{BnF}$ lat. 7295A, also by Conrad Heingarter and probably from the same period, shows the same kind of intellectual profile with more text on instruments. It also contains a version of the Alfonsine tables. 
topics on quires from different origins. When a quire is full he simply moves to a new one. In building this collection, it is not necessary for him to personally copy every text that is to be integrated in the collection. Building a collection is a loosely planned process. The collector is organised. He might have specific targets, and he knows where to place each item in his collection, but he might also be an opportunist and take what is available. The process of building the collection is an integral part of learning the discipline. At some point, for instance when the student changes faculty or finishes his study, the quires which probably circulated in more or less autonomous ways are bound together in a more definitive way (in that case even with clasps). Learning a discipline by building and studying a collection of texts are two related processes centred on the actor who is creating the manuscript.

By contrast, BnF lat. 7432 seems to be the result of a different process, where the actor producing the manuscript is not creating it for himself but uses it to convey a specific message to a given audience (in that case reduced to a dedicatee and its court). The central purpose of 7432 is to demonstrate Conrad Heingarter's competence as an astrologer. In this situation, the production process is very different and far more organised, especially with respect to the external aspects. The supply of quires, the systematic organisation of the different layers of writing (main text, diagrams, tables, decoration, secondary text, etc.) are very important points for 7432. Everything is planned to give the manuscript a unified, and luxurious, external aspect. In order to convey its message efficiently to its audience, the manuscript must be presented suitably. It must also give to the audience a positive self-representation. In the case of 7432, this occurs through the expensive supply of parchment and the even more impressive decorative apparatus and iconographic programme.

Other features of the two manuscripts opened windows on the relation between the production process and the related astronomical practices. One primary, and maybe original, aspect concerns the specific role of the analysis of implicit and inscribed dates and places attached to the two codices. Astronomy is a science that deals with space and time, and the comparison of the two sets of dates and places is a way to understand the articulations between producing astronomical manuscripts and other astronomical practices. 7197 contains a wide range of dates and places because the process of learning encourages the confrontation with various situations, whereas 7432 includes a smaller range of dates and places, because the content had to be adapted to the specific context of the dedicatee.

The contents of the manuscripts also reflect the kind of production process from which the two codices originated. In 7197, the half-organised collecting process which produced the manuscript is reflected in the contents. Most common 
texts of the arts faculty disciplines are found, but also very rare texts. The types of annotation and diagram are also very specific to the learning process. They are sometimes also found in pecia manuscripts that could be used by students as ready-made collections. The intellectual profile of 7432 is also affected by this necessity to convey a specific message. While the art faculty student was interested in arithmetic and mathematical astronomy, the grown-up man, presented his competence in astrology. This competence is displayed mainly by the production of a continuous commentary, adapted to the dedicatee, of the discipline's main texts. The version of the Alfonsine tables in each manuscript marks an interesting contrast between the two documents. In 7432, the Alfonsine tables' version is standard and directly coherent with the choice of John of Saxony's canons. In 7197, the Alfonsine tables are abridged and not coherent with John of Saxony's canons. In the first case, the choice of a standard version and the coherence between the mathematical astronomy texts reinforce the demonstration of competence conveyed by the manuscript. In the second case, the more dialectic relation between the tables and the canons was certainly thought-provoking for the student. Finally, the contrast between the technical diagrams attached in both manuscripts to the Theorica planetarum Gerardi is also important. 7197's annotated diagrams show Conrad Heingarter's intellectual engagement with the content, while 7432's illuminated or even miniaturised diagrams point to the display and decorative features of diagrams. In a nutshell, the production process which created 7197 is generally oriented toward learning activities. Similarly, the production process which created 7432 is generally oriented toward conveying a message of competence to a specific courtly audience. These two manuscripts attest two specific ways for mathematical astronomy to be integrated in late medieval societies. 


\section{References}

Andrist, Patrick / Canart, Paul / Maniaci, Marilena (2013), La syntaxe du codex. Essai de codicologie structurale (Bibliologia: Elementa ad Librorum Studia Pertinentia, 34), Turnhout: Brepols.

Bataillon, Louis J. / Guyot, Bertrand G. / Rouse, Richard H. (eds) (1988), La production du livre universitaire au Moyen Age : exemplar et pecia. Actes du symposium tenu au Collegio San Bonaventura de Grottaferrata en mai 1983. Paris: CNRS Éditions.

Beaujouan, Guy (1974), 'Observations et calculs astronomiques de Jean de Murs', in Actes du $14^{e}$ congrès international d'histoire des sciences, 2: 27-30.

Beaujouan, Guy (1964), EPHE IVe section, annuaire 1964-1965, 259.

Boudet, Jean-Patrice (1994), Lire dans le ciel. La bibliothèque de Simon de Phares, astrologues du $X V^{e}$ siècle. Bruxelles: Centre d'étude des manuscrits.

Briquet, Charles Moise (1907), Les filigranes: dictionnaire historique des marques du papier dès leur apparition vers 1282 jusqu'en 1600. Paris: Alphonse Picard et fils

Brizzi, Gian Paolo / Tavoni, Maria Gioia (eds) (2009), Dalla pecia all'e-book. Libri per l'università : stampa, editoria, circolazione e lettura. Atti del Convegno internazionale di studi, Bologna, 21-25 ottobre 2008. Bologna: CLUEB.

Gushee, Laurence (1970), 'New Sources for the Biography of Johannes de Muris', in Journal of the American Musicological Society, 22: 3-26.

Husson, Matthieu (2016), 'Exploring the Temporality of complex computational Practice: two Eclipse Notes by John of Murs in the MS Escorial 0 II 10', in Centaurus, 58: 46-65.

J. Chabás, José / Goldstein, Bernard R. (2003), The Alfonsine Tables of Toledo. Dordrecht, Boston: Springer.

Josserand, Pierre / Bruno, Jean (1960), Les estampilles du Département des imprimés de la Bibliothèque nationale. Paris: Librairie d'Argences.

Juste, David (2015), Catalogus Codicum Astrologorum Latinorum, II. Les manuscrits astrologiques latins conservés à la Bibliothèque nationale de France à Paris. Paris: CNRS Éditions.

Nothaft, Philipp (2018), Scandalous Error: Calendar Reform and Calendrical Astronomy in Medieval Europe. Oxford: Oxford University Press.

Poulle, Emanuel (1984), Les tables Alfonsines avec les canons de Jean de Saxe. Paris: CNRS Éditions.

Wickersheimer, Ernest / Beaujouan, Guy (1979), Dictionnaire biographique des médecins en France au Moyen âge, nouv. éd. sous la dir. de Guy Beaujouan. Genève, Paris: Droz / Champion, 107. 